\title{
Heterotopic ossification in lymph node metastasis after rectal cancer resection: a case report and literature review
}

Hideki Nagano ${ }^{1,2^{*}} \mathbb{D}$, Tamotsu Togawa ${ }^{1}$, Takeshi Watanabe ${ }^{1}$, Kenji Ohnishi ${ }^{1}$, Toshihisa Kimura', Atsushi lida ${ }^{1}$, Sakon Noriki ${ }^{3}$, Yoshiaki Imamura ${ }^{3}$, Yasunori Sato ${ }^{4}$ and Takanori Goi ${ }^{5}$

\begin{abstract}
Background: Heterotopic ossification $(\mathrm{HO})$ is the formation of osseous tissue outside the skeleton. $\mathrm{HO}$ in malignant tumors of the digestive tract is extremely rare, as is ossification in metastatic lesions from HO-negative digestive tract tumors. Regarding the pathogenesis of $\mathrm{HO}$, two theories have been proposed. The first is that the osteoblastic metaplasia of tumor cells (driven by the epithelial-mesenchymal transition, EMT) results in $\mathrm{HO}$, and the second is that factors secreted by cancer cells lead to the metaplasia of stromal pluripotent cells into osteoblasts. However, the osteogenic mechanisms remain unclear.

Case presentation: An 83-year-old Japanese woman underwent low anterior rectal resection for rectal cancer before presentation at our institution, in June 2018. The final diagnosis was stage IIB rectal adenocarcinoma (T4aNOMO). Histological examination did not reveal $\mathrm{HO}$ in the primary tumor. Thirteen months after the operation, a solitary metastatic lesion in the brain $20 \mathrm{~mm}$ in size and a solitary metastatic lesion in a right axillary lymph node $20 \mathrm{~mm}$ in size were diagnosed. The patient was treated with gamma-knife therapy for the brain metastasis. One month later, she was referred to our institution. She underwent lymph node resection. Histological examination revealed that most portions of the affected lymph node were occupied by metastatic tumor cells and that central necrosis and four small ossified lesions without an osteoblast-like cell rim were present in the peripheral region. Immunohistochemical analysis showed tumor cells positive for BMP-2, osteonectin, osteocalcin, AE1/AE3, TGF- $\beta 1$, Gli2, Smad2/3, and CDX2 and negative for nestin, CD56, and CK7.
\end{abstract}

Conclusion: This is the first English case report of $\mathrm{HO}$ in a metachronous metastatic lymph node after the curative resection of HO-negative rectal cancer. Unlike $\mathrm{HO}$ lesions in past reports, the $\mathrm{HO}$ lesion did not show peripheral osteoblast-like cells, and the immunohistochemical findings indicated that the present case resulted from the EMT.

Keywords: Heterotopic ossification, Rectal cancer, Lymph node, Epithelial-mesenchymal transition, Osteoblast-like cell, BMP-2, TGF- $\beta 1$, Gli2

\footnotetext{
* Correspondence: naganohideki06s@gmail.com

'Department of Surgery, National Hospital Organization Tsuruga Medical Center, 33-1, Sakuragaoka Tsuruga, Fukui 914-0195, Japan

${ }^{2}$ Department of Surgery, Municipal Tsuruga Hospital, 1-6-60, Mishima-cho, Tsuruga, Fukui 914-8502, Japan

Full list of author information is available at the end of the article
}

(C) The Author(s). 2021 Open Access This article is licensed under a Creative Commons Attribution 4.0 International License, which permits use, sharing, adaptation, distribution and reproduction in any medium or format, as long as you give appropriate credit to the original author(s) and the source, provide a link to the Creative Commons licence, and indicate if changes were made. The images or other third party material in this article are included in the article's Creative Commons licence, unless indicated otherwise in a credit line to the material. If material is not included in the article's Creative Commons licence and your intended use is not permitted by statutory regulation or exceeds the permitted use, you will need to obtain permission directly from the copyright holder. To view a copy of this licence, visit http://creativecommons.org/licenses/by/4.0/ The Creative Commons Public Domain Dedication waiver (http://creativecommons.org/publicdomain/zero/1.0/) applies to the data made available in this article, unless otherwise stated in a credit line to the data. 


\section{Background}

Heterotopic ossification ( $\mathrm{HO})$ is bone tissue formation outside the skeleton; the lesion may be benign or malignant $[1,2]$. This phenomenon has been reported in tumors of various organs, including the lung, breast, thyroid, parotid, pancreas, liver, and kidney [3-7]. There are rare reports of $\mathrm{HO}$ in the gastrointestinal tract, with the greatest prevalence in the colon and rectum; however, to date, there have been only 18 English reports of $\mathrm{HO}$ cases derived from primary rectal cancer. The presence of $\mathrm{HO}$ lesions in both primary rectal cancer and metastatic lymph nodes has been reported in only one case [8]. Although there are a few reports of HO lesions in sites of recurrence, such as the lungs or laparotomy sites [3, 9], HO in metachronous metastatic lymph nodes from rectal carcinoma has not been reported in the English literature, to the best of our knowledge. Herein, we report a case of $\mathrm{HO}$ in a metachronous metastatic lymph node in the right axillary region after curative surgery for rectal cancer without $\mathrm{HO}$ and treatment by gammaknife therapy for metachronous brain metastasis without $\mathrm{HO}$. The purpose of this article is to highlight the histopathological and immunohistochemical findings of $\mathrm{HO}$ in the metastatic lymph node and consider the pathogenesis of $\mathrm{HO}$ in the present case.

\section{Case presentation}

An 83-year-old Japanese woman underwent laparoscopic low anterior rectal resection accompanied by bilateral lymph node dissection for rectal cancer without neoadjuvant chemotherapy at a domestic general hospital in June 2018. Preoperative diagnostic imaging that included chest to pelvic computed tomography (CT) showed no high-density spots in the rectal tumor and no distant metastasis. The histopathological diagnosis of the tumor was rectal adenocarcinoma, T4aNOM0, stage IIB, consisting of high-to-low differentiation grade. After the surgery, she presented with anastomotic leakage and underwent temporary ileostomy; the leakage healed 3 months after the rectal resection. Considering the tumor stage and the patient's advanced age, adjuvant chemotherapy was not applied. She underwent closure of the ileostoma in January 2019. In July 2019, she was diagnosed with a metastatic brain lesion $20 \mathrm{~mm}$ in size on the left prefrontal cortex with cerebral edema and a metastatic right axillary lymph node enlarged to $20 \mathrm{~mm}$ in size without small high-density spots by CT (Supplement 1 ). She was treated with gamma-knife therapy with a total of $20 \mathrm{~Gy}$ of irradiation, and the metastatic brain tumor and cerebral edema disappeared. Because of the recurrence, the previous surgeon reconsidered the policy for adjuvant chemotherapy and applied chemotherapy consisting of oral S1 (composed of tegafur and gimeracil, the latter being an inhibitor of dihydropyrimidine dehydrogenase) for the metastatic right axillary lymph node in August 2019. The patient moved to the city of Tsuruga with her family and was referred to the Tsuruga Medical Center in October 2019. She presented a round-shaped, swollen solitary lymph node in the right axillary region that was not fixed to the adjacent structures. The serum levels of epithelial tumor markers, such as carcinoembryonic antigen (CEA; $12.5 \mathrm{ng} / \mathrm{ml}$ ), carbohydrate antigen 19-9 (CA19-9; $187.7 \mathrm{U} / \mathrm{ml})$, and cancer antigen 125 (CA125; $41 \mathrm{U} / \mathrm{ml})$, were elevated. Plain CT (64-row multidetector CT, Aquilion, TSX-101A, Toshiba, Japan) showed a solitary swollen lymph node in the right axillary region, $37 \times 33 \mathrm{~mm}$, with small highdensity spots in the peripheral region (Fig. 1). We performed lymph node resection under the tentative diagnosis of right axillary lymph node metastasis with

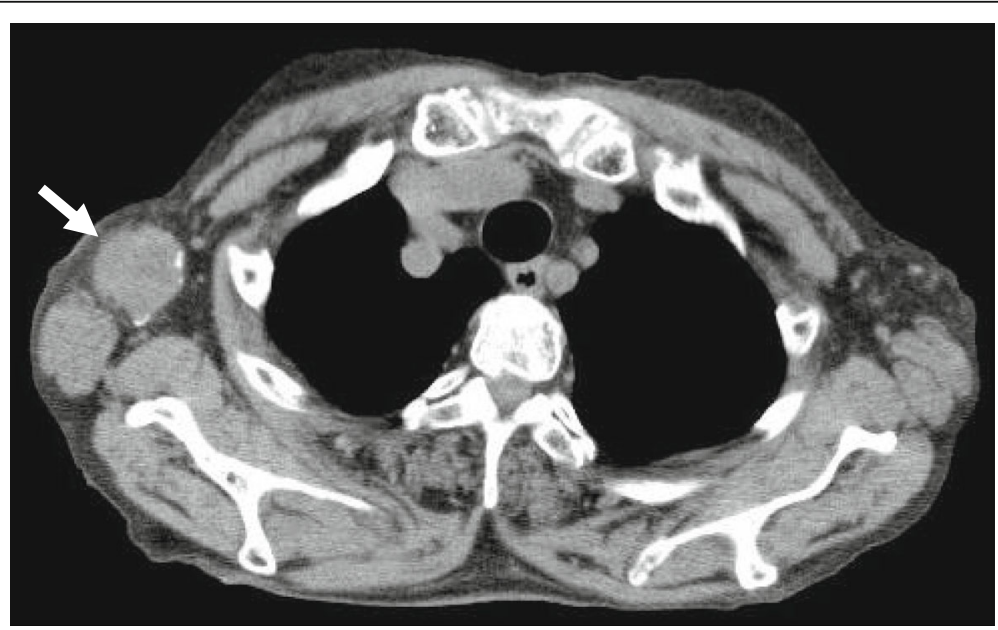

Fig. 1 Findings of CT performed in October 2019. A solitary swollen lymph node measuring $37 \times 33 \mathrm{~mm}$ in size with small high-density spots in the peripheral region was observed in the right axillary region (arrow) 

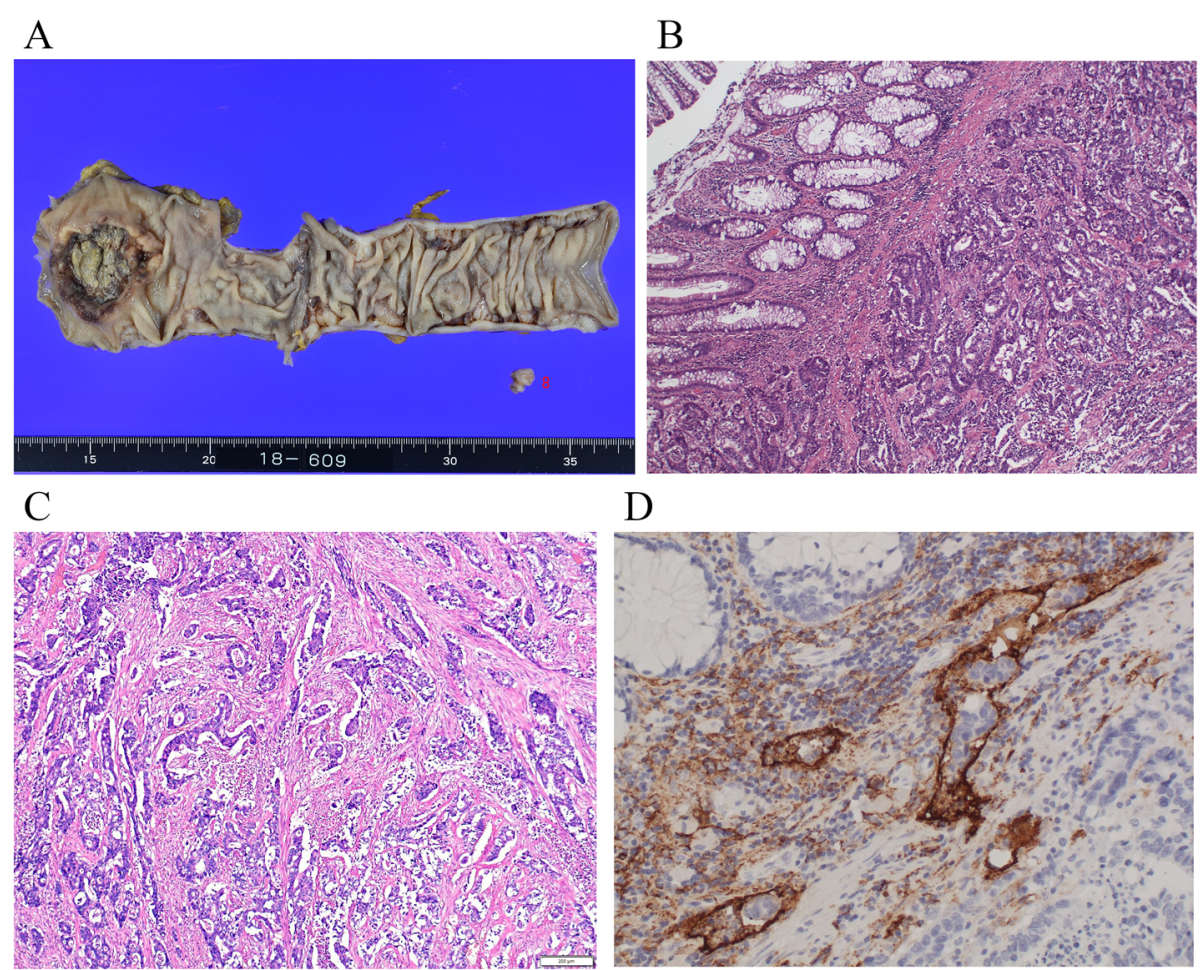

$\mathrm{D}$

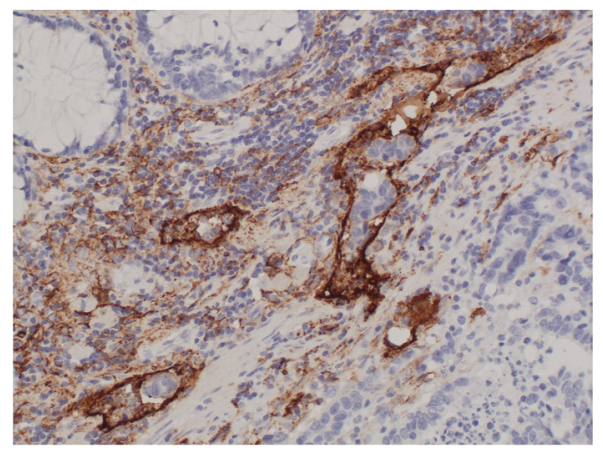

Fig. 2 a Gross appearance of resected rectal cancer. The resected specimen contains a polypoid tumor accompanied by an ulcer with a fungating polypoid component, measuring $48 \times 46 \mathrm{~mm}$. b Microscopy of the primary tumor. The primary tumor was mainly composed of moderately differentiated adenocarcinoma. $\mathbf{c}$ In a portion of the tumor, poorly differentiated carcinoma components were found. $\mathbf{d}$ Scattered lymphatic invasion was found (immunostaining by D2-40)

calcified deposits from rectal cancer in November 2019. The patient showed an uneventful recovery, and chemotherapy consisting of tegafur-uracil/calcium folinate (UFT/UZEL) was initiated 10 days after the operation; she was discharged on the thirteenth postoperative day. She was admitted to the internal medicine section of our hospital for acute pneumonia in January 2020. Chest CT revealed acute pneumonia and swollen right axillary lymph nodes $(42 \times 34 \mathrm{~mm}$ and $24 \times 18 \mathrm{~mm}$ in size $)$ without high-density spots (Supplement 2A, B). The pneumonia progressed rapidly, and the patient died 4 days later. An autopsy was not carried out because her family did not provide consent.

\section{Pathological findings}

\section{Gross pathology of the primary rectal tumor}

The rectal tumor was cut and opened. The resected specimen consisted of a polypoid tumor accompanied by an ulcer with a fungating polypoid mass, measuring $48 \times 46 \mathrm{~mm}$ and occupying two-thirds of the circumference of the lower to middle rectum (Fig. 2a). The distal margin was $10 \mathrm{~mm}$.

\section{Microscopy of the primary tumor}

The primary tumor was mainly composed of moderately differentiated adenocarcinoma, and in a portion of the tumor, well-differentiated adenocarcinoma and poorly differentiated carcinoma components were found (Fig. 2 b and c). Scattered lymphatic and venous invasion (Fig. 2d) and perineural invasion were noted. Ossified areas were not seen in the primary tumor. In the lymph nodes resected with the primary rectal tumor, metastasis was not found.

\section{Pathological findings of the axillary lymph node}

The axillary lymph node contained metastatic adenocarcinoma that was D-PAS and alcian blue positive; the primary lesion also stained positive, but there was no retention of mucin in the interstitial tissue (Fig. 3a, b). Most portions of the lymph node were occupied by metastatic tumor cells. Extensive necrosis was observed in the central region of the node and was accompanied by interstitial fibrosis; the metastasized tumor cells were directly adjacent to necrosis (Fig. 3c). The metastatic adenocarcinoma was a poorly to moderately differentiated adenocarcinoma with a trabecular and cribriform pattern. In the peripheral region of the lymph node, four small ossified lesions were found, and the metastasized tumor cells were directly adjacent to ossified nests (Fig. $3 d)$. Osteocytes were observed inside the osseous matrix; however, osteoblast-like cells were not found around the 
heterotopic osseous lesion (Fig. 3e), and hematopoietic fatty marrow was not observed.

\section{Azan staining and immunohistochemical staining of the axillary lymph node (details of the antibodies used are provided in Supplement 3)}

Staining with Azan revealed collagen-rich stroma in the metastatic lesion (Fig. 4a). Immunostaining for neuroendocrine markers such as chromogranin A (Fig. 4b) and synaptophysin (Fig. 4c) showed negative staining in the metastatic lesion as well as in the primary lesion. (The immunostaining protocol is described in Supplement 4.) Positive staining for caudal-type homeobox 2 (CDX2) was observed in both the primary tumor (Fig. $4 \mathrm{~d}$ ) and metastatic lymph node (Fig. 4e), suggesting that the lymph node lesion was a metastasis of rectal cancer. The tumor cells were negative for CD56 (an osteoblast marker) (Fig. 4f) and CK7 (Fig. 4g). Cells positive for CD68 (a macrophage cell marker) were observed around the osseous lesion (Fig. 4h). CD68-positive cells were also seen in the primary tumor (Fig. 4i).

Bone morphogenetic protein 2 (BMP-2) was observed to be weakly positive in the tumor cells in the metastatic lymph node (Fig. 4j), the luminal membrane of the primary tumor (Fig. 4k), and adjacent normal mucosa (Fig. 41); the primary tumor was judged to be negative for BMP-2. The metastatic tumor cells were also positive for osteonectin (Fig. 4m), osteocalcin (Fig. 4n), cytokeratin AE1/AE3 (Fig. 4o), transforming growth factor- $\beta 1$ (TGFB1) (Fig. 4p), transcription factor glioma-associated oncogene protein 2 (Gli2) (Fig. $4 \mathrm{q}$ ), and phosphorylated Smad2/3 (pSmad2/3) (Fig. 4r) but were negative for nestin (Fig. 4s), murine double minute 2 (MDM2, data not shown), and cluster of differentiation 34 (CD34, data not shown). Figure 4o showed AE1/AE3-positive osteocytes in the HO lesion. BMP- 2 and TGF- $\beta 1$ expression was observed in the cytoplasm of the tumor cells, whereas Gli2 and pSmad2/3 expression was observed in the nucleus of the tumor cells. The expression of alpha-smooth muscle actin ( $\alpha$-SMA) was observed in fibroblasts surrounding the osseous nests (Fig. 4t).

\section{Discussion}

$\mathrm{HO}$ is the formation of osseous tissue outside the skeleton. This phenomenon has been observed in the liver, breast, skin, kidney, lung, thyroid, pancreas, and so on [3-7]. According to 2 review articles, the most common sites of $\mathrm{HO}$ in the gastrointestinal tract are the colon and rectum $[10,11]$. The first 2 cases of rectal adenocarcinoma with bone formation were described by Hasegawa [12] in a report published in German in 1923. Since Dukes [13] provided the first report in the English literature of heterotopic bone formation in rectal carcinoma, describing 2 cases, in 1939, there have been, to the best of our knowledge, 18 reported cases of $\mathrm{HO}$ in primary rectal carcinoma $[6,7,10,11,13-25]$ written in English. Only one of these cases involved an HO lesion in a metastatic lymph node [8] (Table 1). Additionally, Goswami [2] reported a case in which a metastatic lymph node with $\mathrm{HO}$ was simultaneously dissected with the primary rectal carcinoma lesion, which was without $\mathrm{HO}$. However, $\mathrm{HO}$ in a lymph node with metachronous metastasis associated with rectal cancer without $\mathrm{HO}$ has not yet been reported. Only three cases, including the present case, of $\mathrm{HO}$ in a metastatic lymph node from rectal carcinoma have been reported in English to date $[2,8]$. While the two previous cases involved synchronous $\mathrm{HO}$ in the regional metastatic lymph nodes, the present case involved metachronous $\mathrm{HO}$ in the distant lymph node. Moreover, the prior two cases involved an osteoblast-like cell rim, which was absent in our case.

Regarding the pathogenesis of $\mathrm{HO}$, two hypotheses have been proposed: The first is that the epithelialmesenchymal transition (EMT) upregulates tumor cell production of osteogenic factors and induces osteoblastlike transformation, which stimulates uncommitted mesenchymal stromal cells toward osteoblastic differentiation and contributes to heterotopic bone formation [10, $26,27]$. The second is that a diversity of BMP-secreting tumor cells stimulates the osteogenic metaplasia of undifferentiated stromal mesenchymal cells or fibroblasts into osteoprogenitor cells. The second hypothesis seems to account for most cases [15, 28-30]. Among the 18 reported cases of primary rectal cancer with $\mathrm{HO}$, osteoblast-like cells were present in 12 cases; in the remaining 6 cases, their presence or absence was not described. However, in the present case, neither osteoblastlike cells nor pluripotent stromal cells were observed around the osseous matrix, and the carcinoma cells showed osteonectin, osteocalcin, BMP-2, TGF- $\beta 1$, and Gli2 expression.

Osteonectin was strongly positive, and osteocalcin was weakly positive in the tumor cells. These proteins are noncollagenous components of the bone secreted by osteoblasts.

BMP-2 is associated with osteogenic activity and can stimulate bone formation [31], actively inducing the osteoblastic differentiation of both immature osteoblasts and less committed cells; its overexpression in rectal adenocarcinoma cells was first reported by Kypson et al. [19]. BMPs are a group of TGF molecules that have the ability to induce bone and cartilage formation, and TGF$\beta 1$ activity strongly enhances BMP-2 activity [32]. TGF$\beta$ is known to induce the EMT, whereby epithelial tumor cells acquire an invasive, mesenchymal-like phenotype [33]. The presence of TGF- $\beta 1$ in tumor cells demonstrated by immunohistochemistry suggests that tumor cells secrete this factor into the microenvironment, 


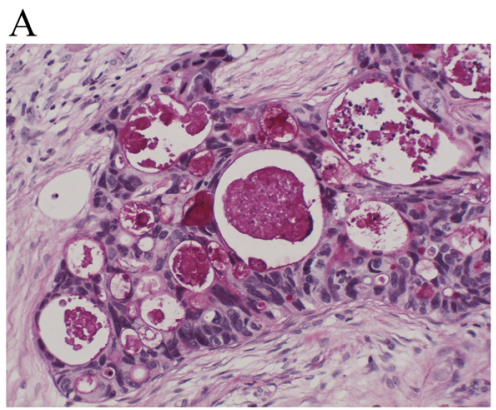

C

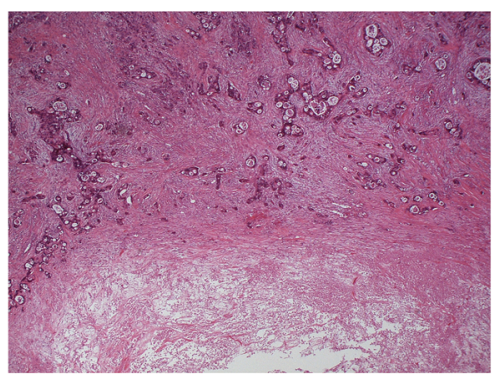

$\mathrm{E}$

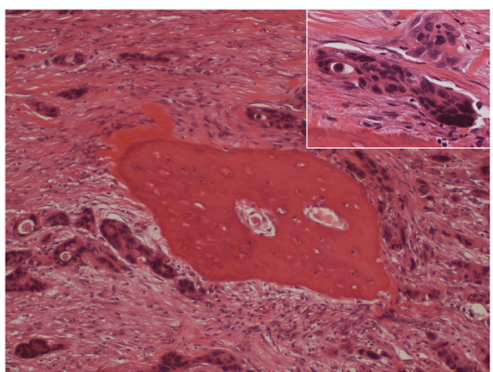

B

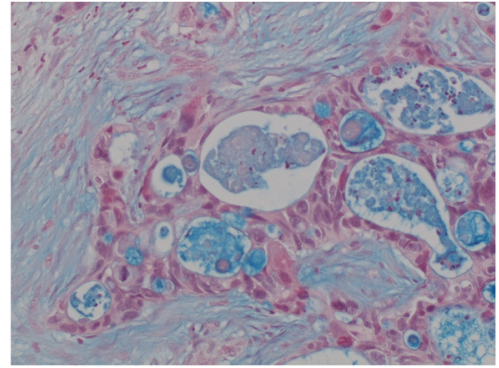

D

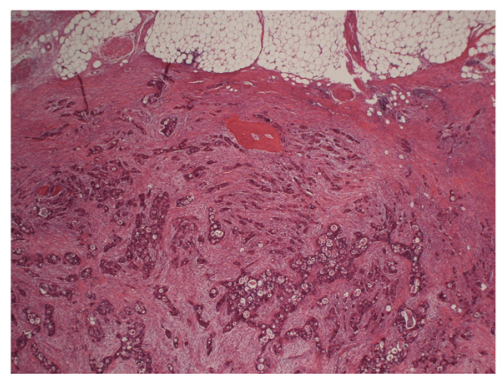

F. 3 Microscopic findings of the axillary lymph node. a Metastatic tumor cells contained mucin as indicated by D-PAS staining; however, mucin retention in the stroma was not observed. b The tumor cells were also found positive for mucin by alcian blue staining. $\mathbf{c}$ Necrosis was observed in the central region of the node, and the metastasized tumor cells were directly adjacent. $\mathbf{d}$ In the peripheral region of the lymph node, four small ossified lesions were found, and the metastasized tumor cells were directly adjacent to ossified nests (arrow) ( $\times 40$ ). e Osteocytes were observed inside the osseous matrix; however, osteoblast-like cells were not found around the HO lesion ( $\times 100)$. The upper right is a magnified view of the tumor cells beside the $\mathrm{HO}$ lesion

which might, much like BMP-2, stimulate pluripotent stromal cells or fibroblasts to transform into osteocytes [1]. The expression of $\alpha$-SMA was observed in fibroblasts surrounding the osseous nests. TGF- $\beta 1$ can induce $\alpha$-SMA expression in fibroblasts, which further implicates the occurrence of TGF- $\beta 1$ activity in the microenvironment [34-36]. TGF- $\beta 1$ activates Smad (through the Smad pathway) and p38MAPK (through the nonSmad-dependent pathway). These two factors converge at runt-related transcription factor 2 (Runx2), which is the most upstream transcription factor essential for osteoblast differentiation, to induce bone formation [37]. Gli2, a downstream molecule of TGF- $\beta$ signaling involved in driving cancer progression toward metastasis, provides cancer cells with a more aggressive phenotype and metastatic ability [33]. In addition, Gli2 can stimulate the production of BMP [38, 39]. Unlike in past reports, in the present case, osteoblast-like cells or pluripotent cells were not observed around the HO lesion, and the metastatic adenocarcinoma cells themselves produced every ossification factor and bone material and served the role of osteoblasts. This process seems to resemble the pathogenesis of fibrous dysplasia, a skeletal condition in which normal bone is replaced by poorly organized bone and fibrous tissue with little to no osteoblastic rim [40].

Regarding the intermediate filaments, generally, it is thought that tumors with intermediate filament conversion, such as vimentin-expressing tumors, have high malignancy. In the present case, the tumor cells were positive for AE1/AE3 and negative for nestin, which is an intermediate filament protein abundant in embryonic 
Table 1 Reported cases of primary rectal cancer with heterotopic ossification [7, 8, 10, 11, 13-25]

\begin{tabular}{|c|c|c|c|c|c|c|c|c|c|}
\hline \multirow{2}{*}{ Case } & \multicolumn{2}{|c|}{ Reference } & \multirow{2}{*}{$\begin{array}{l}\text { Age } \\
69\end{array}$} & \multirow{2}{*}{$\begin{array}{l}\text { Gender } \\
M\end{array}$} & \multirow{2}{*}{$\begin{array}{l}\text { LN metastasis } \\
\text { present }\end{array}$} & \multirow[t]{2}{*}{$\begin{array}{l}\text { Ossification in } \\
\text { LN metastasis }\end{array}$} & \multirow{2}{*}{$\begin{array}{l}\text { Metastasis to } \\
\text { other organ }\end{array}$} & \multirow[t]{2}{*}{$\begin{array}{l}\text { Ossification in } \\
\text { metastases }\end{array}$} & \multirow{2}{*}{$\begin{array}{l}\begin{array}{l}\text { osteoblast- } \\
\text { like cell }\end{array} \\
\text { NA }\end{array}$} \\
\hline & 1939 & Dukes [13] & & & & & & & \\
\hline 2 & 1939 & Dukes [13] & 32 & $\mathrm{~F}$ & - & & NA & & + \\
\hline 3 & 1951 & Christie [14] & 44 & $\mathrm{~F}$ & + & NA & NA & & + \\
\hline 4 & 1962 & Urbanke [15] & 55 & $\mathrm{~F}$ & NA & & NA & & + \\
\hline 5 & 1988 & Byard [16] & 72 & M & NA & & NA & & NA \\
\hline 6 & 1992 & Ansari [10] & 54 & $\mathrm{~F}$ & - & & + & NA & + \\
\hline 7 & 1993 & Pai [17] & 46 & M & + & - & NA & & NA \\
\hline 8 & 1996 & Haque [11] & 78 & M & NA & & NA & & + \\
\hline 9 & 1997 & Beauchamp [18] & 64 & M & + & NA & NA & & + \\
\hline 10 & 2003 & Kypson [19] & 38 & $\mathrm{~F}$ & - & & - & & NA \\
\hline 11 & 2004 & Matsumoto [20] & 67 & M & + & - & - & & NA \\
\hline 12 & 2004 & Szumilo [21] & 79 & M & + & - & NA & & + \\
\hline 13 & 2005 & Al-Maghrabi [22] & 90 & $\mathrm{~F}$ & + & NA & - & & + \\
\hline 14 & 2010 & Nagao [8] & 46 & M & + & + & NA & & + \\
\hline 15 & 2011 & Badmos [7] & 48 & M & - & & NA & & + \\
\hline 16 & 2015 & Smajda [23] & 29 & $\mathrm{~F}$ & + & NA & + & NA & NA \\
\hline 17 & 2016 & Shimazaki [24] & 57 & M & + & NA & NA & & + \\
\hline 18 & 2017 & Liu [25] & 76 & M & + & - & - & & + \\
\hline
\end{tabular}

stem-derived progenitor cells that can differentiate into cells of various lineages, including mesodermal cells [41], and be used for the analysis of osteoblasts. These results suggest that the tumor cells might have obtained the ability to form bone without intermediate filament conversion; however, the observed negativity for nestin alone does not seem sufficient to confirm or negate this possibility. In the $\mathrm{HO}$ lesion, cytokeratin-positive osteocytes were also observed (Fig. 4o), and the results suggest the possibility that the tumor cells induce the metaplasia of fibroblasts to osteocytes via the EMT.

Mucin, necrosis, and desmoplastic stroma are considered relevant factors of $\mathrm{HO}[9,11,13,42]$. In the present case, the tumor cells contacted necrotic lesion directly, but mucin or desmoplastic stroma was not observed in the interstitial tissue. Minute ossified lesions were in contact with tumor cells but were not in direct contact with necrotic tissue. The influence of necrosis on $\mathrm{HO}$ in this case is unclear. Smajda et al. [23] reported HO in association with FOLFOX6 administration followed by a combination of capecitabine and radiotherapy. In the present case, at the time of diagnosis of axillary lymph node metastasis in July 2019, HO was not detected by $\mathrm{CT}$, and administration of an anticancer agent (S1) was begun following diagnosis $\mathrm{HO}$ subsequently appeared in the peripheral portion of the lymph node in October 2019. S1 consisted of tegafur, a 5-fluorouracil (5FU) prodrug. Yu et al. [43] reported that 5FU treatment elevated the expression of hedgehog target genes GLI1 and GLI2 in gastric cancer. The hedgehog pathway plays a role in bone formation as it allows the differentiation of mesenchymal progenitor cells into osteoblast cells [44]. In our case, it is possible that chemotherapy-induced activation of the hedgehog pathway contributed to the overexpression of Gli2 and resulted in HO. Figure 5 shows a schematic representation of the $\mathrm{HO}$ in the present case. The $\mathrm{HO}$ lesions observed in this case were $<1 \mathrm{~mm}$ and identified mainly by CT imaging. To definitively diagnose the presence or absence of $\mathrm{HO}$, investigation of 1-mm slices of the entire primary rectal tumor is necessary; however, this was technically impossible in our case. We conducted a CT scan of the stored gross specimens of the primary tumor and axillary lymph node. The scan revealed that the primary tumor was negative for high-density spots, whereas the lymph node was positive (Fig. 6). Based on the negative BMP-2 findings for the primary lesion, the preoperative $\mathrm{CT}$ of the primary tumor, and the CT scans of the specimens, we concluded that $\mathrm{HO}$ was not evident in the primary tumor. Metastasis to a lymph node in the axillary region occurred, but the positive reaction for $\mathrm{CDX} 2$ and the negative reaction for CK7 indicated that the metastatic foci were from rectal cancer and not from unknown breast cancer.

Generally, there are two pathogenic mechanisms of ossification: membranous ossification or endochondral ossification under normal conditions and $\mathrm{HO}$ under pathological conditions. With respect to $\mathrm{HO}$, it seems 


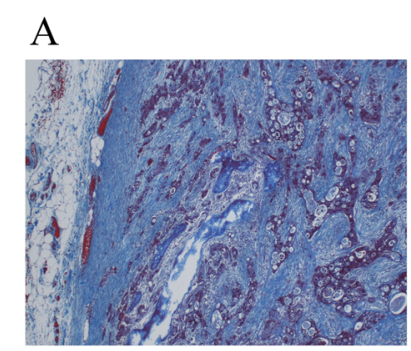

E
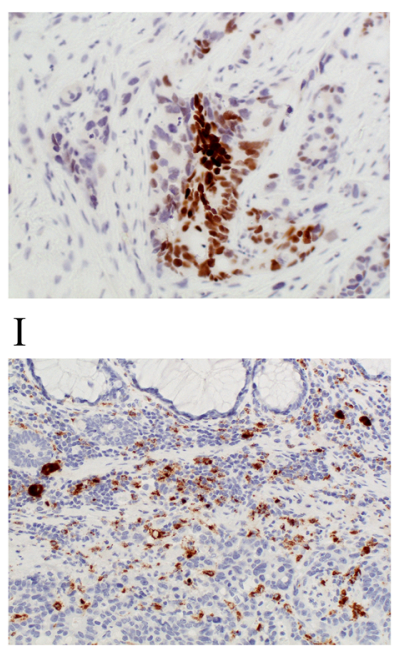

M

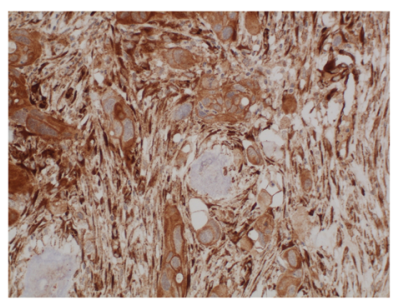

Q
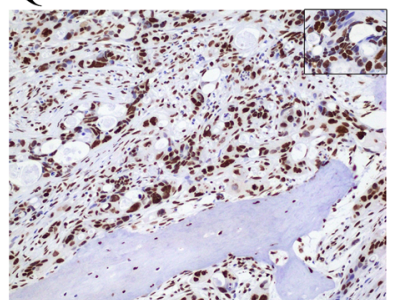

B

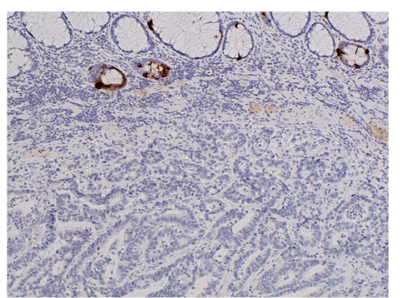

F

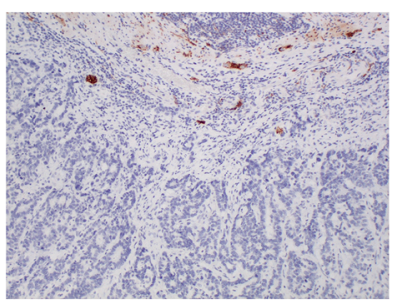

$\mathrm{J}$

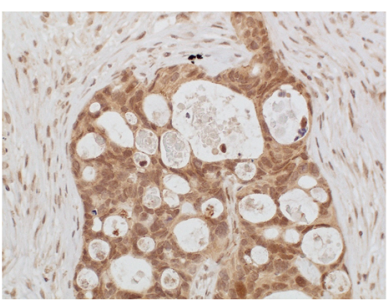

$\mathrm{N}$

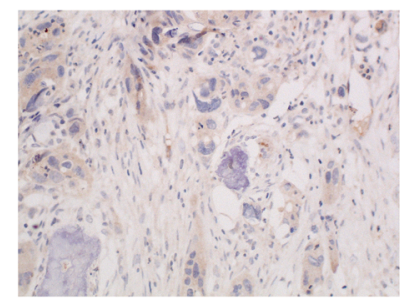

$\mathrm{R}$

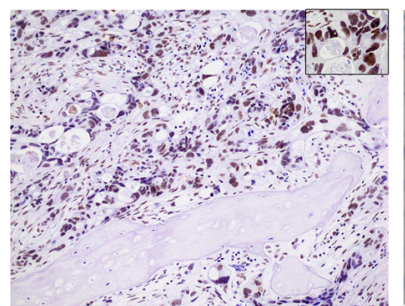

C

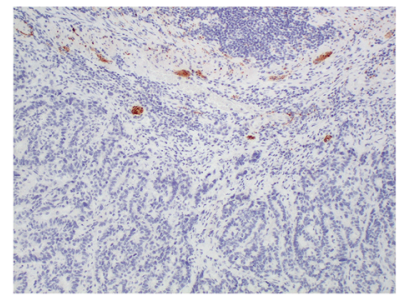

G

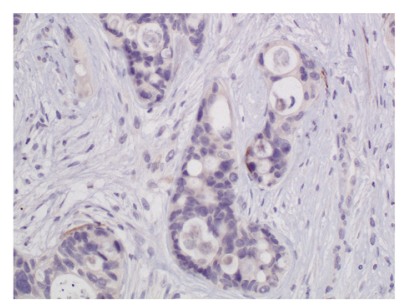

K

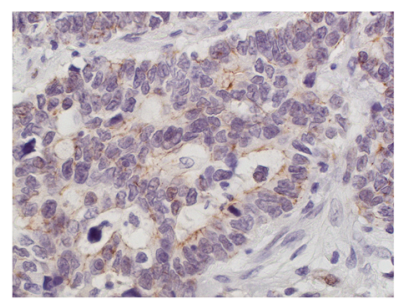

$\mathrm{O}$

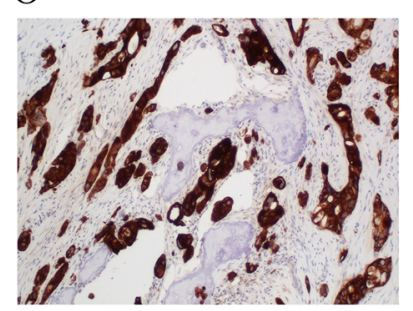

$\mathrm{S}$

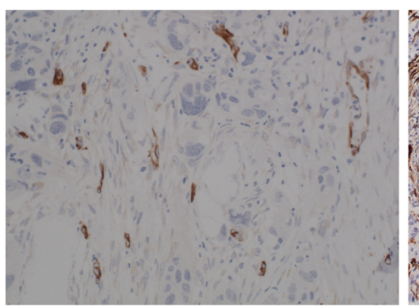

D

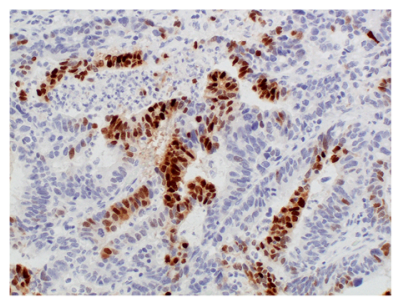

$\mathrm{H}$

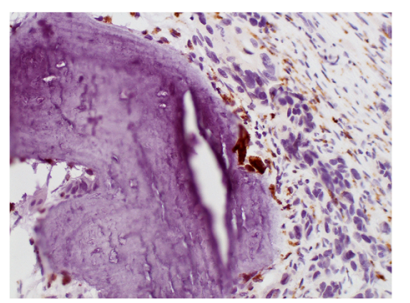

$\mathrm{L}$

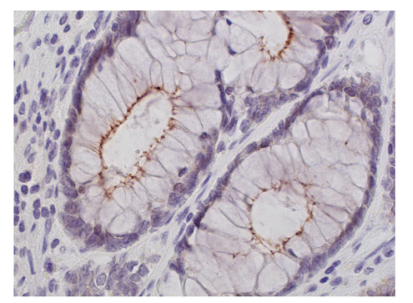

$\mathrm{P}$

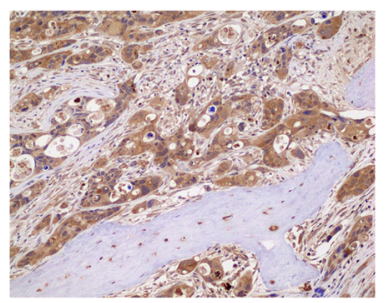

$\mathrm{T}$

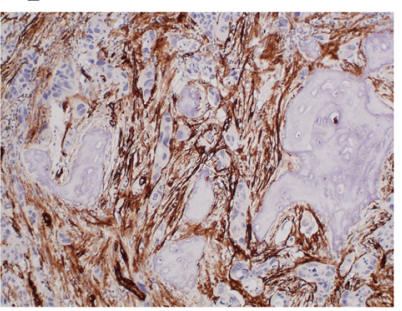

Fig. 4 Findings of Azan staining and immunohistochemical staining of the axillary lymph node. a Azan staining showed that the metastatic tumor lesion was collagen rich $(\times 40)$. b Immunohistochemical staining using an antibody for chromogranin A showed negative staining in the metastatic tumor lesion as well as in the primary lesion. c The tumor cells also showed negative staining for synaptophysin. $\mathbf{d}$ The primary tumor cells showed positive staining for CDX2 in the nucleus $(\times 200)$. e The tumor cells in the lymph node also showed positive staining for CDX2 $(\times$ 200). $\mathbf{f}, \mathbf{g}$ The tumor cells in the lymph node were negative for osteoblast marker CD56 (f) and breast cancer marker CK7 (g). $\mathbf{h}$ Cells positive for the macrophage cell marker CD68 were observed around the osseous lesion. $\mathbf{i}$ CD68-positive cells were also seen in the primary tumor. $\mathbf{j}$ The tumor cells showed BMP-2 overexpression in the lymph node $(\times 400)$. $\mathbf{k}$, I BMP-2 expression was weakly positive in the cell membrane on the lumen side of the primary tumor $(\mathbf{k}: \times 400)$ and adjacent normal mucosa $(\mathbf{I}: \times 400) . \mathbf{m}, \mathbf{n}$ Osteonectin expression was strongly positive $(\mathbf{m}: \times 200)$ and osteocalcin expression was weakly positive $(\mathbf{n}: \times 200)$ in the tumor cells. o, $\mathbf{p}$ The tumor cells expressed cytokeratin (AE1/AE3) (o: $\times 200)$ and TGF- $\beta 1$ (p: $\times 200 ;{ }^{*} \mathrm{HO}$ tissue). In the HO lesion, cytokeratin-positive osteocytes were observed (o: arrows). q, $\mathbf{r}$ Gli2 (q: $\left.\times 200\right)$ and pSmad2/3 (r: $\times$ 200) showed overexpression in the nucleus of the tumor cells ( ${ }^{*} H O$ tissue). The upper right of $\mathbf{q}$ and $\mathbf{r}$ are magnified views $(\times 400)$. $\mathbf{s}$ The tumor cells showed no nestin expression $(\times 200)$. $\mathbf{t}$ Fibroblasts surrounding the tumor cells showed alpha-smooth muscle actin (a-SMA) expression $(\times 100)$ 


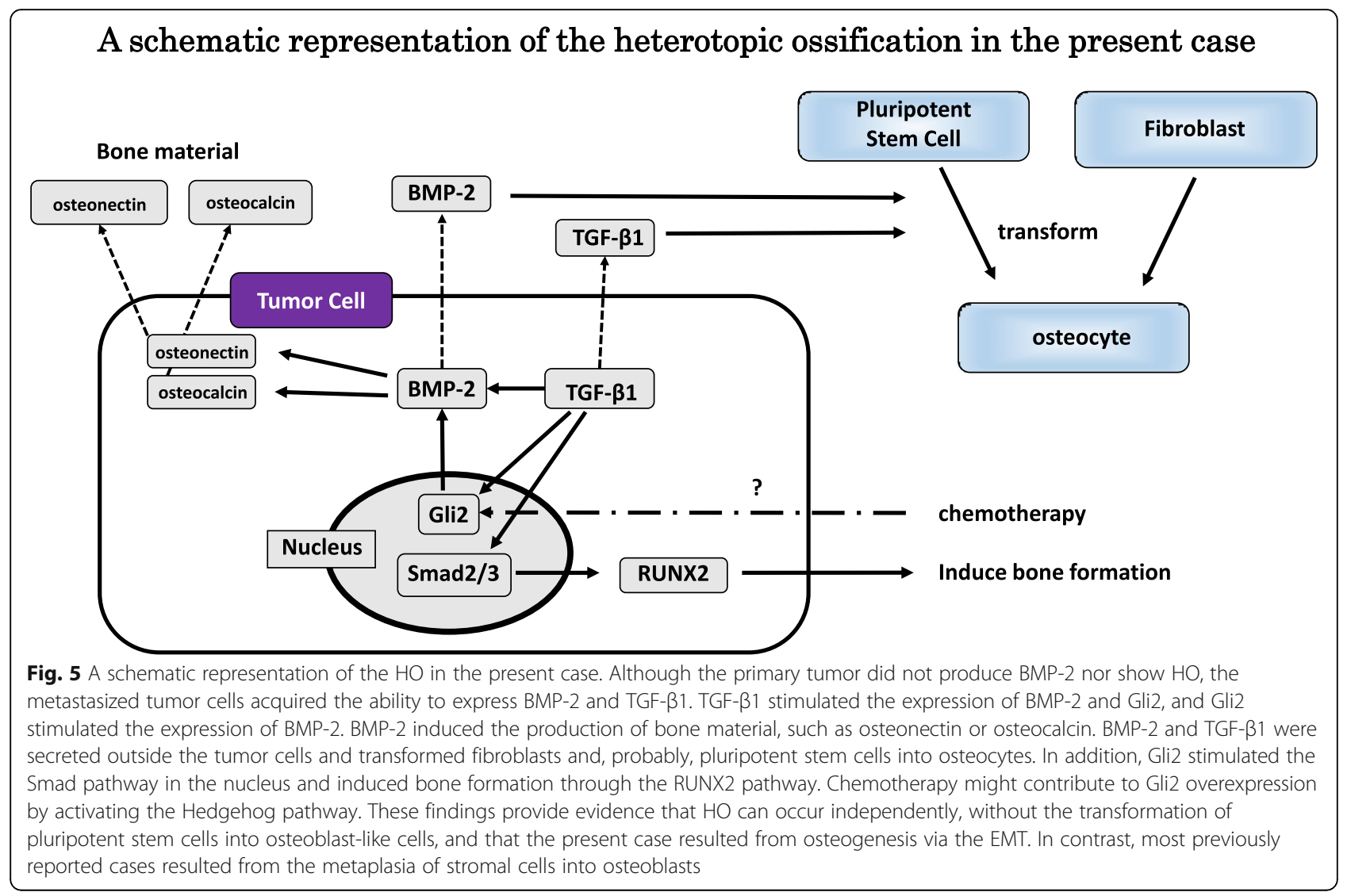

that there are many pathogenic mechanisms that have yet to be elucidated.

Axillary lymph node metastases recurred 2 months after resection of the right axillary metastatic lymph node. At the time of recurrence to the same region, $\mathrm{HO}$ was not detected by CT. Although a pathological diagnosis was not obtained from the recurrent axillary lymph nodes, HO might not always occur even if similar adenocarcinoma cells metastasize, and there might be an optimum condition for $\mathrm{HO}$ considering the secretion of factors by tumor cells.

\section{Conclusions}

We report the first case of $\mathrm{HO}$ in a metachronous metastatic lymph node from rectal cancer without HO. Unlike in past reports, in the present case, neither osteoblast-like cells nor pluripotent cells were observed around the HO lesions, and the metastatic adenocarcinoma cells produced ossification factors and bone material. These findings indicated that the present case resulted from osteogenesis via the EMT; in contrast, most previously reported cases resulted from the metaplasia of stromal cells into osteoblasts. The

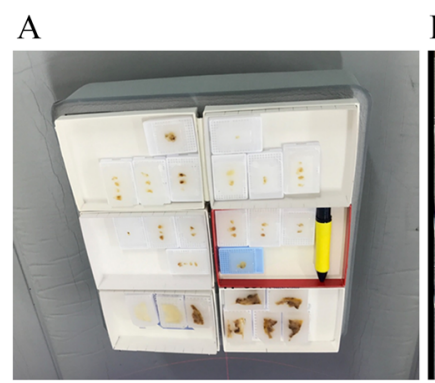

B

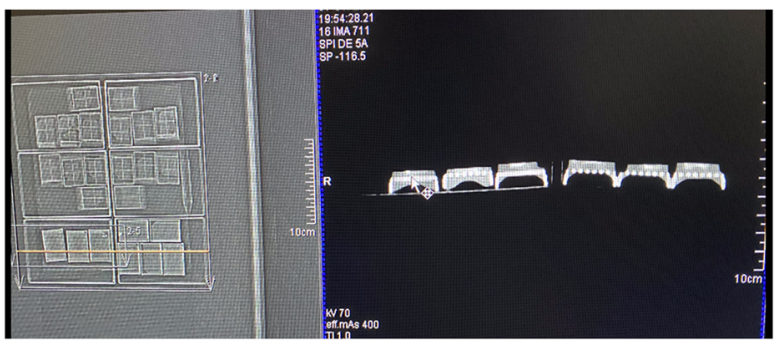

Fig. $\mathbf{6}$ CT findings of the paraffin block of the rectal cancer, regional lymph nodes, and axillary lymph node. a The specimen blocks were set on the CT. Two left lower blocks, outlined in red, are of axillary lymph node with ossification. $\mathbf{b}$ The yellow horizontal line of the left image indicates the scan level of the CT. The left-hand side of the right image shows the CT of the axillary lymph node, and a minute high-density spot was apparent in the left specimen (arrow); however, not such spot was observed in the primary tumor specimen 
documentation and detailed analysis of additional cases are necessary.

\section{Supplementary Information}

The online version contains supplementary material available at https://doi. org/10.1186/s12957-020-02098-x.

Additional file 1: Supplement 1. CT findings of the recurrent right axillary lymph node in June 2019. A metastatic lymph node enlarged to $20 \mathrm{~mm}$ in size without small high-density spots was found (arrow); then, administration of an anticancer agent (S1) was begun. Supplement 2. Findings of CT performed in January 2020. Axillary lymph node metastases recurred $(42 \times 34 \mathrm{~mm}$ and $24 \times 18 \mathrm{~mm}$ in size; $\mathrm{A}$ : arrow, B: arrows) two months after resection of the right axillary metastatic lymph node. Despite the recurrence in the same region, high-density spots were not observed in the lymph nodes. Supplement 3. Details of the antibodies used in the present case. Supplement 4. The immunostaining protocol used in the present case.

\section{Abbreviations}

HO: Heterotopic ossification; CT: Computed tomography;

CEA: Carcinoembryonic antigen; CA19-9: Carbohydrate antigen 19-9; CA125: Cancer antigen 125; UFT/UZEL: Tegafur uracil/calcium folinate; CDX2: Caudal-type homeobox 2; CD56: Cluster of differentiation 56; CK7: Cytokeratin 7; CD68: Cluster of differentiation 68; BMP-2: Bone morphogenetic protein-2; TGF- $\beta 1$ : Transforming growth factor- $\beta 1$; Gli2: Transcription factor glioma-associated oncogene protein 2; pSmad2/ 3: Phosphorylated Smad2/3; MDM2: Murine double minute 2; CD34: Cluster of differentiation 34; a-SMA: Alpha smooth muscle actin; EMT: Epithelialmesenchymal transition; MAPK: Mitogen-activated protein kinase; Runx2: Runt-related transcription factor 2; FOLFOX: Folic acid, fluorouracil, oxaliplatin; 5FU: 5-Fluorouracil

\section{Acknowledgements}

Not applicable

\section{Authors' contributions}

$\mathrm{HN}$ performed preoperative investigation and lymph node resection and drafted the manuscript. TT, TW, and KO performed preoperative investigation. TK, Al, and TG provided academic advice. SN conducted the pathological examination and immunostaining. $\mathrm{YI}$ and YS performed the immunostaining. SN, $\mathrm{Yl}$, and $\mathrm{YS}$ provided us the interpretation of the results. All authors have read and approved the final manuscript.

\section{Funding}

None of the authors have any sources of funding to disclose.

\section{Availability of data and materials}

All data generated or analyzed during this study are included in this published article.

\section{Ethics approval and consent to participate}

All procedures used in this research were approved by the Ethics Committee of the National Hospital Organization Tsuruga Medical Center.

\section{Consent for publication}

Written informed consent was obtained from the patient's family for the publication of this case report and any accompanying images. A copy of the written consent form is available for review by the Editor-in-Chief of this journal.

\section{Competing interests}

The authors have no competing interests to declare.

\section{Author details}

'Department of Surgery, National Hospital Organization Tsuruga Medical Center, 33-1, Sakuragaoka Tsuruga, Fukui 914-0195, Japan. ²Department of Surgery, Municipal Tsuruga Hospital, 1-6-60, Mishima-cho, Tsuruga, Fukui 914-8502, Japan. ${ }^{3}$ Division of Surgical Pathology, University of Fukui Hospital,
23-3 Matsuokashimoaizuki, Eiheiji-cho, Yoshida-gun, Fukui 910-1193, Japan. ${ }^{4}$ Institute of Medical, Pharmaceutical and Health Sciences, Faculty of Medicine, Kanazawa University, 13-1 Takara-machi, Kanazawa, Ishikawa 920-8641, Japan. ${ }^{5}$ First Department of Surgery, Faculty of Medicine, University of Fukui, 23-3, Matsuokashimoaizuki, Eiheiji-cho, Yoshida-gun, Fukui 910-1193, Japan.

Received: 13 August 2020 Accepted: 26 November 2020

Published online: 02 January 2021

\section{References}

1. Richard Sheng PH, Brown R, Buryanek J. Heterotopic ossification in metastatic colorectal carcinoma: case report with morphoproteomic insights into the histogenesis. Ann Clin Lab Sci. 2014;44:1.

2. Goswami M. Rectal adenocarcinoma with heterotopic ossification in metastatic lymph nodes: an unusual case. Nat J Lab Med. 2017:6:PL01-2.

3. Clark A. Heterotopic bone formation associated with adenocarcinoma in an abdominal scar. Br J Surg. 1935;22:889-90.

4. An T, Grathwohl M, Frable WJ. Breast carcinoma with osseous metaplasia: an electron microscope study. Am J Clin Pathol. 1983:80:127-32.

5. Maeda M, Kanayama M, Uchida T. A case of hepatocellular carcinoma associated with ossification. Cancer. 1986:57:134-7.

6. Fukuoka T, Honda M, Namiki M. Renal cell carcinoma with heterotopic bone formation. Urol Int. 1987:42:458-60.

7. Badmos KB, Seada LS, Faraj AA. Heterotopic ossification in a colorectal carcinoma. J Coll Physicians Surg Pak. 2011:21:626-7.

8. Nagao Y, Shimajiri S, Katsuki T. Rectal carcinoma with heterotopic bone: report of a case. Case Rep Gastroenterol. 2010;4:351-5.

9. Van Patter HT, Whittick JW. Heterotopic ossification in intestinal neoplasms. Am J Pathol. 1955;31:73-91.

10. Ansari MQ, Sachs IL, Max E. Heterotopic bone formation in rectal carcinoma. Case report and literature review. Dig Dis Sci. 1992;37:1624-9.

11. Haque $\mathrm{S}$, Eisen $\mathrm{RN}$, West $\mathrm{AB}$. Heterotopic bone formation in the gastrointestinal tract. Arch Path Lab Med. 1996;120:666-70.

12. Hasegawa T. Zur Kenntnins der Stromaverknöcherung in Karzinomen des Digestionstraktes. Wien Klin Wochenschr. 1923;36:653-56.7.

13. Dukes CE. Ossification in rectal cancer. Proc R Soc Med. 1939:32:1489-94.

14. Christie AC. Ossification in intestinal neoplasms: a report of three cases. J Pathol Bacteriol. 1951;63:338-40.

15. Urbanke A. Heterotopic ossification in rectal carcinoma. Gastroenterologia. 1962:98:48-53.

16. Byard RW, Thomas MJ. Osseous metaplasia within tumours. A review of 11 cases. Ann Pathol. 1988:64-6.

17. Pai SA, Bhasin SD, Krishnamurthy SC. Heterotopic ossification in colorectal adenocarcinoma. Indian J Pathol Mircobiol. 1993;36:304-7.

18. Beauchamp NJ, Pizer $E_{1}$ Hruban RH, Fishman EK. Ossification of a rectal tumor: CT evaluation. J Comput Assist Tomogr. 1997;21:671-3.

19. Kypson AP, Morphew E, Jones R, Gottfried MR, Seigler HF. Heterotopic ossification in rectal cancer: rare finding with a novel proposed mechanism. J Surg Oncol. 2003:82:132-6.

20. Matsumoto T, Masuda T, Inomata M, Kitano S, Kashima K, Shibata K, Arinaga S. Heterotopic ossification of rectal adenocarcinoma: report of a case. Surg Today. 2004;34:167-9.

21. Szumilo J, et al. Rectal adenocarcinoma with osseous metaplasia. Pol J Pathol. 2004:55:39-40

22. Al-Maghrabi H, Jamison BM, Veinot JP. Calcified colonic mass. Arch Pathol Lab Med. 2005:129:1347-8.

23. Smajda S, Danse E, Mertens de Wilmars M, Humblet $Y$, Kartheuse A, JouretMourin A. Ossification of a rectal tumor: an uncommon finding. Acta Gastroenterol Belg. 2015;78:431-5.

24. Shimazaki J, Takemura A, Nishida K, Kajiyama H, Shimoda M, Suzuki S. Heterotopic ossification in rectal carcinoma: report of a case and review of the literature Case Rep Oncol. 2016:6:698-704

25. Liu X, Xu J, Chen L. Colorectal carcinoma with osseous metaplasia. Oncotarget. 2017:8:65407-13

26. Noh BJ, Kim YW, Park YK. A rare colon cancer with ossification: pathogenetic analysis of bone formation. Ann Clin Lab Sci. 2016:46:428-32.

27. Huang RS, Brown RE, Buryanek J. Heterotopic ossification in metastatic colorectal carcinoma: case report with morphoproteomic insights into the histogenesis. Ann Clin Lab Sci. 2014;44:99-103. 
28. Leriche R, Policard A. "The normal and pathological physiology of bone: its problems". Moore S, Key JA, translators. London: Henry Kimpton, $1928,236 \mathrm{pp}$

29. Rhone DP, Horowitz RN. Heterotopic ossification in the pulmonary metastasis of gastric adenocarcinoma: report of a case and review of the literature. Cancer. 1976;38:1773-80.

30. Imai N, Iwai A, Hatakeyama S. Expression of bone morphogenetic proteins in colon carcinoma with heterotopic ossification. Pathol Int. 2001;51:643-8.

31. Wozney JM, Rosen V, Celeste AJ. Novel regulators of bone formation: molecular clones and activities. Science. 1988;242:1528-34.

32. Tachi K, Takami M, Sato H. Enhancement of bone morphogenetic protein-2 induced ectopic bone formation by transforming growth factor- $\beta 1$. Tissue Eng Part A. 2011;17:597-606.

33. Javelaud D, Alexaki V, Dennler S. The TGF- $\beta / S M A D / G L I 2$ signaling axis in cancer progression and metastasis. Cancer Res. 2011;71:5606-10.

34. Desmoulière A, Geinoz A, Gabbiani F. Transforming growth factor-beta 1 induces alpha-smooth muscle actin expression in granulation tissue myofibroblasts and in quiescent and growing cultured fibroblasts. J Cell Biol. 1993;122:103-11.

35. Roy SG, Nozaki Y, Phan SH. Regulation of alpha-smooth muscle actin gene expression in myofibroblast differentiation from rat lung fibroblasts. Int J Biochem Cell Biol. 2001;33:723-34.

36. Feng XH, Derynck R. Specificity and versatility in tgf-beta signaling through Smads. Annu Rev Cell Dev Biol. 2005;21:659-93.

37. Chen G, Deng D, Li YP. TGF- $\beta$ and BMP signaling in osteoblast differentiation and bone formation. Int J Biol Sci. 2012;8:272-88

38. Zhao M, Qiao M, Harris SE. The zinc finger transcription factor Gli2 mediates bone morphogenetic protein 2 expression in osteoblasts in response to hedgehog signaling. Mol Cell Biol. 2006;26:6197-208.

39. Zhao M, Ko SY, Liu JH. Inhibition of microtubule assembly in osteoblasts stimulates bone morphogenetic protein 2 expression and bone formation through transcription factor Gli2. Mol Cell Biol. 2009;29:1291-305.

40. Nelson BL, Phillips BJ. Benign fibro-osseous lesions of the head and neck. Head Neck Pathol. 2019;13:466-75.

41. Wiese C, Rolletschek A, Kania G. Nestin expression-a property of multilineage progenitor cells? Cell Mol Life Sci. 2004;61:2510-22.

42. Lauwers GY, Wahl SJ, Richard GK. Osseous metaplasia in colonic adenocarcinoma. Am J Gastroenterol. 1991;86:382.

43. Yu B, Gu D, Zhang X, Liu B, Xie J. The role of GLI2-ABCG signaling axis for 5FU resistance in gastric cancer. J Genet Genomics. 2017;44:375-83.

44. Regard JB, Malhotra D, Gvozdenovic-Jeremic J, Josey M, Chen M, Weinstein LS, Lu J, Shore EM, Kaplan FS, Yang Y. Activation of Hedgehog signaling by loss of GNAS causes heterotopic ossification. Nature Medicine. 2013;19: $1505-12$.

\section{Publisher's Note}

Springer Nature remains neutral with regard to jurisdictional claims in published maps and institutional affiliations.

Ready to submit your research? Choose BMC and benefit from:

- fast, convenient online submission

- thorough peer review by experienced researchers in your field

- rapid publication on acceptance

- support for research data, including large and complex data types

- gold Open Access which fosters wider collaboration and increased citations

- maximum visibility for your research: over $100 \mathrm{M}$ website views per year

At $\mathrm{BMC}$, research is always in progress.

Learn more biomedcentral.com/submissions 